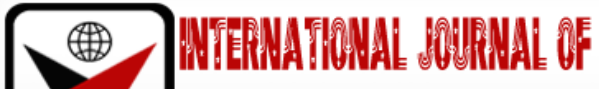

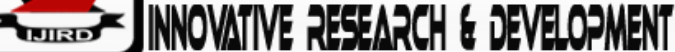

ISSN 2278 - 0211 (Online)

\section{Prevalence of Hepatitis Infection in Relation to Education and Occupational Status of Patients Attending Primary Health Care Clinics in Taraba North Senatorial District of Taraba State, Nigeria}

\author{
Ihedigbo, P.O. \\ Student, Federal University of Agriculture Makurdi, Benue State, Nigeria \\ Ega, R.A.I \\ Professor, Federal University of Agriculture Makurdi, Benue State, Nigeria \\ Amali, 0. \\ Professor, Federal University of Agriculture Makurdi, Benue State, Nigeria \\ Gberikon, G.M. \\ Associate Professor, Federal University of Agriculture Makurdi, Benue State, Nigeria
}

\begin{abstract}
:
Investigations were carried out to ascertain the prevalence of hepatitis $A, B$ and $C$ infections in relation to education and occupational status of patients attending primary health care clinics in Taraba North Senatorial District of Taraba State, Nigeria. Blood Samples were aseptically collected from 383 consented individuals with 128 samples collected from each of the 3 local Government areas (Ardo-Kola, Jalingo and Yorro LGA), samples were examined using rapid qualitative diagnostic tests method to screen for Hepatitis $A, B$ and $C$ viruses by the detection of viral markers in the blood. Risk factors relating to hepatitis were obtained using a questionnaire. Results showed that viral hepatitis $A$ did not show significant statistical association $(P>0.05)$. However seroprevalence of hepatitis $B$ and $C$ surface antigen differed significantly $(P<0.05)$. In this study, those without education (non - literate) were mostly affected with HCV with a percentage value of $13.8 \%$. A higher prevalence of $10.8 \%$ for HBV was recorded among those with secondary school education, and highest prevalence of $12.3 \%$ was recorded for both HBV and HCV in post - secondary school education. In occupational status, farmers were worst hit with HVC infection (11.6\%). It was established from findings of this study that prevalence of viral hepatitis $C$ and $B$ pose serious health concern in the study area. Therefore, emphasis on awareness and immunization by appropriate authorities should be encouraged to reduce spread of infection.
\end{abstract}

Keywords: Occupation, education, hepatitis

\section{Introduction}

Hepatitis viruses (Viral hepatitis) are the most common cause of hepatitis in the world, (WHO, 2016).Viral Hepatitis may be caused by at least five distinct viruses known as types, A, B, C, D, or E. When the liver is inflamed, it does not perform its functions well, which brings about many of the symptoms, signs, and problems associated with any type of hepatitis (CDC, 2016). Viral hepatitis infection is a global health challenge, affecting 400 million people worldwide, over 10 times the number of people infected with HIV. Globally, about 1.4 million people die each year from hepatitis (WHO, 2016).Countries with the greatest prevalence include Africa, South America, Eastern European countries, and Asian countries. However incidence and mortality rates vary with each type of the disease: Hepatitis A is a disease of the liver caused by hepatitis A virus (HAV). It is spread by faecal-oral route. Person-to-person transmission is also common and generally limited to close contacts. The infection is associated with unsafe water or food, inadequate sanitation and poor personal hygiene such as regular washing of hands (WHO, 2016). HAV has a global distribution like other enteric infectious diseases with the highest prevalence in developing countries, such as Africa (Cameroon, Morocco and Nigeria.), Asia, Central and South America, where environmental and socio-economic conditions favour the propagation or early exposure of this virus among young children with severity of infection with increase in age (WHO,2008). Improvements in public health sanitation have led to a decline in the incidence of hepatitis A infections in the developed countries such as North America and Western Europe to increase rate and risk of infection among older age groups (Pischke et al., 2012). Hepatitis B is one of the major and common infections of the liver worldwide. It is caused by hepatitis B virus (HBV), a small DNA virus and can cause both acute and chronic disease progressing to cirrhosis and liver cancer and at last death (Mbaawuaga et al., 2008). Hepatitis C is a liver disease caused by hepatitis $C$ 
virus (HCV) infection is also a major global health issue. The infection is spread through contact with the blood of an infected person, primarily through sharing needles, syringes, or other injection drug equipment. Although uncommon, Hepatitis $\mathrm{C}$ can also be spread through sexual contact. Having a sexually transmitted disease (STD) or HIV, sex with multiple partners, or rough sex appears to increase a person's risk for Hepatitis C (CDC, 2013).

\section{Materials and Methods}

\subsection{Selection of Sample Population and Sample Description}

Primary health care based selection of subjects was adopted with no age and sex restriction. Three Local Government Areas from Taraba North Senatorial District which include Adro- kola, Jalingo and Yorro areas where selected. Three clinics were assigned to me from the office of the Director of health of each of the 3 local Government areas based on the primary health care clinics (PHCC) that has a laboratory facility attached to it. Patients were sampled on the clinical days of the PHCC when a good number of patients/people will come for health care services. Volunteer participants who gave informed consent were included in this study after a brief health talk on Hepatitis during their routine health education.

\subsection{Sample Size}

Raosoft Sample Size Calculator was used to determine the sample size (Raosoft, 2011).A total of 384 participants were recruited in this study, with 128 samples collected from each of the given Local Government Areas of the Taraba North Senatorial District.

\subsection{Sample Collection}

Following research approval and counseling concerning the nature and use of the samples to be collected from the participants, $3 \mathrm{ml}$ of blood were aseptically collected by venipuncture using syringe and needle from each participant and discharged into a vacutainer by a laboratory technician. The blood specimens were transferred into well labeled test tubes with serial number tags and was allowed to clot or centrifuged at $1000 \mathrm{~g}$ for 5 minutes to separate the serum from the whole blood. Serum was aspirated with Pasteur pipette and was used immediately for the test. The screening was carried out in the laboratory unit attached to the PHCC where the samples were collected.

\subsection{Laboratory Analysis}

All sera were analyzed or assayed for Hepatitis A, Hepatitis B and Hepatitis C antibodies. Rapid qualitative screening method for the detection of viral markers in the blood samples specific to each type of hepatitis virus was employed. Thus each serum was tested for antibodies to Hepatitis A virus total antibody using Micro point (USA) One- step rapid Test Kit for screening Hepatitis A virus antibody and both hepatitis B surface antigen and anti-N U hepatitis C antibody were screened using Egens Rapid Diagnostic test Kit (USA).The test procedure was followed according to the manufacturer's instructions.

\subsection{Interpretation of Results}

The test required the use of "test strips" that provides results in approximately 20 minutes. (Food and Drug Administration (FDA), (2010). Positive screening was determined by the appearance of two red bars in both the control and the patient's window strip. The occurrence of only one red bar on the control strip indicated negative screening test. While no red appearance on the control bar or test showed invalid result which has to be repeated for that sample using a new test strip? Point to note: the intensity of the red colour in the bar (line) region varies depending on the concentration of the viral marker present in the specimen. Thus any shade of red bar in the test region is considered positive.

\subsection{Administration of Questionnaires}

Administration of questionnaires was provided for every volunteer in English for the educated and local dialects (through interpreters) for the illiterate rural dweller through personal one on one or small group discussions, with the following information: occupation and educational status (primary, secondary, tertiary, and no form of education

\section{Results and Discussion}




\begin{tabular}{|c|c|c|c|c|c|c|c|}
\hline Educational level & $\begin{array}{c}\text { No } \\
\text { Examined }\end{array}$ & \multicolumn{2}{|c|}{$\begin{array}{c}\text { HAV } \\
\text { No Positive. (\%) }\end{array}$} & \multicolumn{2}{|c|}{$\begin{array}{c}\text { HBV } \\
\text { No Positive. (\%) }\end{array}$} & $\begin{array}{c}\text { HCV } \\
\text { No Positive (\%) }\end{array}$ \\
\hline Post-secondary & 73 & 0 & $(0.0)$ & 9 & $(12.3)$ & 9 & $(12.3)$ \\
\hline Secondary & 111 & 3 & $(2.7)$ & 12 & $(10.8)$ & 12 & $(10.8)$ \\
\hline Primary & 86 & 2 & $(2.3)$ & 7 & $(8.1)$ & 7 & $(8.1)$ \\
\hline Non-literate & 94 & 1 & $(1.1)$ & 3 & $(3.2)$ & 13 & $(13.8)$ \\
\hline Others & 19 & 0 & $(0.0)$ & 0 & $(0.0)$ & 1 & $(5.3)$ \\
\hline Total & 383 & 6 & $(1.6)$ & 31 & $(8.1)$ & 42 & $(11.0)$ \\
\hline
\end{tabular}

Table 1: Prevalence of Viral Hepatitis A B, and C Infections in Relation to Educational Level $P=0.5 \quad 1.12 \quad 0.69$

Key: HAV = Hepatitis A Virus; HBV=Hepatitis B Virus; HCV = Hepatitis C Virus; No = Number; $(\%)=$ Percentage;

Table 2: Prevalence of Viral Hepatitis A B, and C Infections in Relation to Occupation Status of Patients

\begin{tabular}{|c|c|c|c|c|}
\hline Occupation & No Examined & $\begin{array}{c}\text { HAV } \\
\text { Positive. (\%) }\end{array}$ & $\begin{array}{c}\text { HBV } \\
\text { Positive. (\%) }\end{array}$ & $\begin{array}{c}\text { HCV } \\
\text { Positive. (\%) }\end{array}$ \\
\hline Civil Servant & 42 & $1(2.4)$ & $2(4.8)$ & $5(11.9)$ \\
\hline Dependents & 35 & $0(0.0)$ & $1(2.9)$ & $3(8.6)$ \\
\hline Farmers & 138 & $3(2.2)$ & $10(7.2)$ & $16(11.6)$ \\
\hline Health workers & 11 & $1(9.1)$ & $1(9.1)$ & $2(18.2)$ \\
\hline Self-employed & 82 & $1(1.2)$ & $7(8.5)$ & $8(9.8)$ \\
\hline Students & 75 & $0(0.0)$ & $10(13.3)$ & $8(10.7)$ \\
\hline Total & 383 & $6(1.6)$ & $31(8.1)$ & $42(11.0)$ \\
\hline
\end{tabular}

Key: HAV = Hepatitis A Virus, HBV = Hepatitis B Virus, HCV = Hepatitis C Virus, NO = Number, (\%) = Percentage.

\section{Discussion}

Education characterized once lifestyles and safety of social exposure through knowledge and awareness. There was no statistically significant association $(\mathrm{P}>0.05)$ between Hepatitis B seropositivity and level of education among the participants. The higher prevalence of $10.8 \%$ for this infection was recorded among those with secondary school education, meaning they were more exposed than others. However this study is in agreement with the findings of Waje et al. (2016) in Kaduna which recorded a high prevalence rate of $13.85 \%$ among secondary school subjects in a Public Hospital and $26.67 \%$ in a private hospital in Kaduna metropolis, Nigeria. It agrees with the work of Bitiyong (2016) who observed no statistically significant difference $(\mathrm{P}>0.05)$ between hepatitis $\mathrm{B}$ and educational status but obtained highest prevalence among the subjects with no- formal education (non-literate) in Zaria. It also agrees with previous works done outside Nigeria, the findings of both Bakry et al. (2012) and Djeriri et al. (2008) in Sudan and Morocco respectively. This suggest that educational status is not a barrier for positivity or getting infected without being exposed to the virus, that is, one can be infected regardless of once educational background when exposed to the virus. Although it contradicts the findings of Okonkwo et al. (2010) who observed significant difference $(\mathrm{P}<0.05)$ with increased educational status. No significant difference $(\mathrm{P}>0.05)$ was observed in relation to occupation and hepatitis B virus, among the student participants in this study. This finding agrees with the report of Bitiyong (2016) who also observed no significant difference between $(P>0.05)$ the viral infection and occupation, indicating that occupation is not a factor to spreading this virus.

\section{Conclusion}

It was concluded from this study that prevalence of HBV and HCV are higher than HAV. Secondary and post-secondary education levels were mostly affected with HBV and HCV, farmers are worst hit with HCV. Viral hepatitis B and C are major source of public health concern in the study area, therefore appropriate measures should be taken to prevent spread.

\section{References}

i. Bakry, S. H., Mustafa, A.F, Eldalo, A. F, and Yousif, M. A. (2012). "Knowledge, attitude and practice of health care workers toward Hepatitis B virus infection, Sudan," International Journal of Risk and Safety in Medicine, 24(2): 95102.

ii. Bitiyong, R. W. (2016). Detection of Hepatitis C and Hepatitis B Virus Infection Among Prison Inmates and Psychiatric Patients in Kaduna Metropolis, Nigeria. Unpublished MSc. Thesis, Department of Microbiology Ahmadu Bello University, Zaria. Pp. 1-126.

iii. Centers for Disease Control (2016)."Hepatitis B".World Health Organization. Retrieved 2016-03-09. 
iv. Centers for Disease Control and Prevention (CDC) (2013)."Number and rate of deaths with hepatitis C listed as a cause of death, by demographic characteristic and year United States, 2004-2008". Viral Hepatitis on the CDC web site. Centers for Disease Control and Prevention, Atlanta, GA. Retrieved 28 July 2013

v. Djeriri, K., Laurichesse, H and Merle, L. J. (2008). "Hepatitis B in Moroccan health care workers," Occupational Medicine, 58(6): 419-424.

vi. Food and Drug Administration (FDA). (2010). Approves Rapid Test for Antibodies to Hepatitis C Virus. News and Events. Available at: http://www.fda.gov/NewsEvents/Newsroom/PressAnnouncements/ucm217318.htm

vii. Mbaawuaga, E.M., Enenebeaku, M.N.O., Okopi, J.A. and Damen, J.G. (2008).Hepatitis B Virus (HBV) Infection among Pregnant Women I Makurdi, Nigeria.African Journal of Biomedical Research, 11: 155-159.

viii. Okonkwo, I. O., Soleye, F. A., Amusan, T. A.,Udeze, A. O.,Alli, J. A.,Ojezele, M. O., Nwanze, J. C. and Fadeyi, A. (2010). Seroprevalence of HBsAg among patients in Abeokuta, South Western Nigeria.Global Journal of Medical Research, 10(2): 40.

ix. Pischke, S. and Wedemeyer, H. (2012).Hepatitis A. In: Mauss S, Berg T, Rockstroh J, etal.Eds. Hepatology- 3rd edition. Germany. Druckhaus Sud. Flying Publisher. Pp. 27 -31.

x. Raosoft EZReport, EZSurvey, InterForm, RapidReport, (2011). Raosoft, and Survey Win,the registered trademarks of Raosoft, Inc. Retrieved from http://www.raosoft.com/on 23/02/2018.

xi. Waje, T., Muhammad, Y., Dadah, A., Maikaje, D. B. (2016).A Comparative Study on Hepatitis B Surface Antigen Seroprevalence between Outpatients in Public and Private Hospitals within Kaduna Metropolis Nigeria. American Journal of Epidemiology and Infectious Disease, 4(3): 47-63. http://pubs.sciepub.com/ajeid/4/3/2.

xii. World Health Organization (WHO) (2016)."Guildelines for the prevention, care and treatment of persons with chronic hepatitis B infection”.World Health Organization.Retrieved 2016-03-11.

xiii. World Health Organization. (2008) Hepatitis Fact sheet No 204 August 2008. Available at: http://www.who.int/mediacentre/f actsheets/fs204/en/ 